\title{
Plasma Histamine Levels in Patients in the Course of Several Standard Operations: Influence of Anaesthesia, Surgical Trauma and Blood Transfusion
}

\author{
H.D. Röher, W. Lorenz ${ }^{1}$, H. Lennartz, J. Kusche, W. Dietz, B. Gerdes, and J.V. Parkin ${ }^{2}$ \\ Dept. of Surgery, Division of Theoretical Surgery, Centre of Operative Medicine I, Department of Anaesthesia \\ University of Marburg (Lahn), Robert-Koch-Str. 8, D-3550 Marburg, Federal Republic of Germany \\ and Department of Surgical Studies, Middlesex Hospital, London, UK
}

Summary. A prospective controlled clinical trial was conducted on changes in plasma histamine and catecholamine levels during 5 standard operations. This communication, as the first part of the trial, deals only with the feasibility of such a trial and the changes in plasma histamine levels.

Elevated histamine concentrations corresponding to histamine-release responses of $>1 \mathrm{ng} / \mathrm{ml}$ occurred in 8 of 25 operations. In an explorative analysis these reponses were associated with distinct phases of anaesthesia or the surgical procedure.

Blood transfusion carried the risk of infusion of "free histamine" into the patient - especially when administered under pressure.

Since during operations "free histamine" enters the circulation with a rather high incidence and may cause harmful effects, premedication with $\mathrm{H}_{1}-+\mathrm{H}_{2}$-receptor antagonists seems worth consideration.

Key words: Standard operations - anaesthesia - blood transfusion - plasma histamine

\section{Plasmahistaminspiegel bei Patienten im Verlauf von verschiedenen Standardoperationen: \\ Einfluf von Anästhesie, chirurgischem Trauma und Bluttransfusion}

Zusammenfassung. Eine prospektive kontrollierte klinische Studie wurde über Veränderungen des Plasmahistamin- und Katecholaminspiegels bei 5 Standardoperationen durchgeführt. Diese Mitteilung, als erster Teil der Studie, zeigt nur die Möglichkeiten auf, eine solche Studie durchzuführen und Veränderungen des Plasmahistaminspiegels nachzuweisen.

Erhöhte Plasmahistaminkonzentrationen, die einer $\mathrm{Hi}$ staminfreisetzungsreaktion von $>1 \mathrm{ng} / \mathrm{ml}$ entsprechen, $\mathrm{ka}-$ men bei 8 von 25 Operationen vor. In einer explorativen statistischen Analyse wurden diese Reaktionen mit bestimmten Phasen der Anästhesie oder des chirurgischen Eingriffs in Verbindung gebracht.

Bluttransfusionen tragen das Risiko in sich, ,freies Histamin" in den Patienten zu infundieren - zumal bei Filterpassage, wenn es unter erhöhtem Druck angewandt wird.

Offprint requests to: Prof. Dr. H.D. Röher (address see above)

1 Supported by grant of Deutsche Forschungsgemeinschaft (Lo 199/13-6)

2 Supported by the Wellcome Trust, London
Da während Operationen recht häufig ,freies Histamin“" in die Zirkulation gelangt und möglicherweise schädigende Wirkungen entfaltet, ist möglicherweise eine Prämedikation mit $\mathrm{H}_{1}$ - und $\mathrm{H}_{2}$-Rezeptorantagonisten ratsam.

Schlüsselwörter: Standardoperationen - Anästhesie - Bluttransfusion - Plasmahistaminspiegel

Over the past decades numerous publications originating from various medical disciplines dealt with problems of release of biogenic amines (histamine, catecholamines, serotonin) in response to any kind of stress (Schayer 1961, Erspamer 1966; Rocha e Silva 1966; Blaschko and $\mathrm{Mu}$ scholl 1972; Altura and Halevy 1978; Vane and Ferraira 1978). Their role in general cardiovascular reactions like tachycardia, arrhythmia, hypotension and in microcirculatory responses such as oedema, thrombosis and hypoxic tissue damage is still poorly understood, but for obvious reasons these questions are of major interest in surgery.

Earliest studies have focused their attention to a relationship between histamine liberation and shock symptoms primarily due to skin injury (Lewis and Grant 1924; Dagstedt and Mead 1937; Rosenthal and Minard, 1939). However, a role of histamine or of histamine-like substances as vasodepressor material was mostly only speculated since adequate methods for direct measurement of plasma histamine concentrations were not available (Schneider 1930; Rose and Browne 1940). It was only recently that laboratory techniques for reliable and reproducible histamine assays had been developed (Lorenz et al. 1972; Beaven et al. 1972) which could successfully be used to determine histamine release and its significance linked to clinical conditions. Thus, several groups have investigated changes of plasma histamine concentrations and their biological influence in renal and liver transplantation (Thermann et al. 1978; Lorenz et al. 1973), in abdominal surgery (Lorenz et al. 1974, Beger et al., 1975) and in severe polytrauma (Fischer et al. 1978). More than in surgery, however, the role of increased histamine release is documented by now in anaphylactoid reactions to various drugs applied in the course of anaesthesia (Lorenz et al. 1981).

Due to the lack of reliable assays hitherto we could not find any prospective study in the literature which deals with histamine release into the blood circulation and with consecutive disturbances of the cardiovascular system in the course of specific surgical procedures. Therefore we de- 


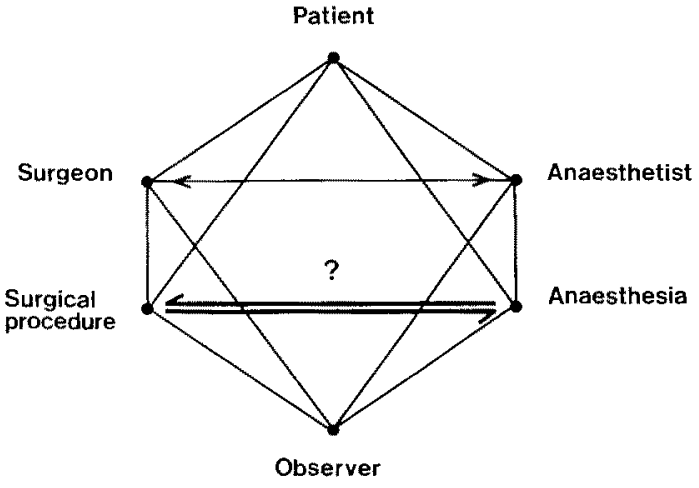

Fig. 1. Histamine and catecholamines in intraoperative cardiovascular disturbances - some interferences in an operational network

signed a project to investigate whether the operative trauma in itself with tissue damage at various sites or manipulation of inner organs such as lungs, intestinal tract or thyroid gland would lead to histamine release which in turn would elicite hazardous reactions like circulatory depression. The first part of this prospective controlled clinical trial in a relatively small number of patients ("pilot" character of the study) dealt only with plasma histamine levels in the course of five kinds of standard operations. Attempts were made to differentiate between the influences of anaesthesia, surgical trauma and blood transfusion.

\section{Materials and Methods}

\section{Theoretical and Ethical Issues}

In summer 1980 a pilot study was conducted in 7 patients to test the feasibility of a controlled clinical trial on the involvement of histamine and catecholamines in intraoperative cardiovascular disturbances.

It revealed the extreme complexity of such a project. The problems and possibilities to introduce biases were really multidimensional including primarily the close and always actual interference of surgical manoeuvres and anaesthesiological procedures (Fig. 1). Thus with no sense the protocol could be set up as a comprehensive controlled trial from the very beginning, but had to be outlined as a prospective "recounting" of facts which could later be attributed to time-dependent obvious events in connection with specific operative phases. Keen observation and meticulous assessment of any events during a normal "daily" operation excluded any specific type of patient monitoring - mainly avoiding non-routinely applied invasive measures. For the same reasons the number of patients included in the present study had to be limited allowing essentially only an explorative statistical analysis of the data accumulated.

Being aware of the great variety of the prognostic factors involved in this study including those of the patient, the surgeon and the anaesthetist, the type of anaesthesia applied and the operative procedure we tried to standardize as much as possible ( $\mathrm{Ta}$ ble 1).

\section{Time Schedule, Patients and Materials}

The trial started with the definition of the clinical problem on May 15, 1980 (Lindenschmidt et al. 1981). The preliminary protocol was completed in October, 1980, the executive group was constituted and a pilot study conducted in 7 patients. By chance, in this trial a life-threatening anaphylactoid reaction occurred in a patient with bronchial carcinoma following infusion of human alburmin in the immediate pre-operative period. The preliminary pro-
Table 1. Problems expected in the trial on histamine and catecholamines in intraoperative cariovascular disturbances and attempts for their solution

\begin{tabular}{|c|c|}
\hline Problems expected & Attempts of their solution \\
\hline Variation of patients & $\begin{array}{l}5 \text { subgroups defined, allocation } \\
\text { at random }\end{array}$ \\
\hline Variation of doctors & $\begin{array}{l}1 \text { surgeon, } 1 \text { anaesthetist, } \\
1 \text { observer }\end{array}$ \\
\hline $\begin{array}{l}\text { Variation of surgical } \\
\text { procedure }\end{array}$ & $\begin{array}{l}5 \text { reasonably homogenous standard } \\
\text { operations }\end{array}$ \\
\hline Variation of anaesthesia & $\begin{array}{l}\text { General and regional anaesthesia ac- } \\
\text { ceptable, but drugs (e.g. hexobarbi- } \\
\text { tone, alcuronium, ethrane or bupiva- } \\
\text { cain etc.) standardized }\end{array}$ \\
\hline $\begin{array}{l}\text { Numerous prognostic } \\
\text { factors }\end{array}$ & $\begin{array}{l}\text { Restriction of sample to } 5 \times 5 \text { patients, } \\
\text { but recording of any event by defined } \\
\text { observer and an additional technician }\end{array}$ \\
\hline Sudden events & $\begin{array}{l}\text { Blood sampling at fixed intervals and } \\
\text { at extra times as free collections }\end{array}$ \\
\hline Amine pharmakokinetics & Central catheterization \\
\hline $\begin{array}{l}\text { Statistics for time- } \\
\text { dependent measurement }\end{array}$ & $\begin{array}{l}\text { ARMA statistics } \\
\text { (auto-regressive average-moving) }\end{array}$ \\
\hline Ethics & $\begin{array}{l}\text { Only intensified observation, volume } \\
\text { of blood sampling within variation of } \\
\text { blood loss }\end{array}$ \\
\hline
\end{tabular}

tocol and the result of the pilot study were presented to the Workshop of Clinical Trials of the German Surgical Society on November 7, 1980 and approved by statisticians and legal experts following several amendments. The modified protocol was completed on December 31, 1980 and accepted by the executive group and the external referees on January $26,1981$.

The trial was conducted in the Dept. of Surgery in Marburg from February 3 - May 19, 1981. Of the 25 patients included in the study there was no drop-out. The random assignment of the subjects to the 5 groups of operation and their attributes are listed in Table 2.

All patients received a considerable number of drugs during the operations, for example the first subject with an aorto-bifemoral Mikrovel bypass 22 different substances. General anaesthesia was performed in 20 subjects, regional anaesthesia in 5 including 4 subjects with bypass operations. The following groups of drugs were administered (definitions according to Laurence and Bennett 1980).

- General, local anaesthetics and hypnotics (Hexobarbital sodium, Evipan (Bayer); etomidat, Hypnomidate (Janssen); flunitrazepam, Rohypnol (Roche); nitrous oxide; halothane, Fluothane (ICIPharma), enfluran, Ethrane (Abbott); bupivacain-HCl (monohydrate), Carbostesin (Astra Chemicals))

- analgesics (pethidine-HCl, Dolantin (Hoechst); fentanyl dihydrogen-citrate, Fentanyl (Janssen))

- neuromuscular blocking agents (pancuronium bromide, Pancuronium "Organon" (Organon Technika); alcuronium chloride, Alloferin (Roche); suxamethonium chloride, Lysthenon (Hormonchemie))

- plasma substitutes and various electrolyte solutions (human albumin, Humanalbin (Behringwerke), hydroxyethyl starch 200/0.4, HAES steril (Fresenius))

- miscellenous drugs (promethazine, Atosil (Bayer); atropine sulfate (Hameln), orciprenaline sulfate, Alupent (Boehringer Ingelheim); neostigmine, Prostigmin (Roche); cafedrine. $\mathrm{HCl}+$ theodrenaline; $\mathrm{HCl}$, Akrinor (Homburg); digoxine, Novodigal (Beiersdorf) 
Table 2. Attributes of the patients in trial, sequence of operations and treatment groups

\begin{tabular}{|c|c|c|c|c|c|}
\hline $\begin{array}{l}\text { No. in } \\
\text { series }\end{array}$ & Name & Age & Sex & $\begin{array}{l}\text { Day of } \\
\text { operation }\end{array}$ & $\begin{array}{l}\text { Group of } \\
\text { operation }\end{array}$ \\
\hline 1 & D.E. & 73 & $\mathrm{~m}$ & Feb 2 & Bypass \\
\hline 2 & Sch.M. & 39 & $\mathrm{f}$ & Feb 6 & Rectum \\
\hline 3 & W.H. & 74 & $\mathrm{~m}$ & Feb 10 & Lung \\
\hline 4 & P.A. & 38 & $\mathrm{f}$ & Feb 12 & Lung \\
\hline 5 & R.H. & 64 & $\mathrm{~m}$ & Feb 17 & Lung \\
\hline 6 & G.H. & 57 & $\mathrm{f}$ & Feb 23 & Gallbladder \\
\hline 7 & M.T. & 38 & $\mathrm{f}$ & Feb 25 & Goitre \\
\hline 8 & T.W. & 73 & $\mathrm{~m}$ & Feb 26 & Bypass \\
\hline 9 & $\mathrm{~K} . \mathrm{J}$. & 54 & $\mathrm{~m}$ & Feb 27 & Gallbladder \\
\hline 10 & G.K. & 70 & $\mathrm{f}$ & Mar 10 & Goitre \\
\hline 11 & G.K. & 63 & f & $\operatorname{Mar} 13$ & Rectum \\
\hline 12 & W.H. & 69 & $\mathrm{~m}$ & Mar 16 & Rectum \\
\hline 13 & K.A. & 48 & $\mathrm{f}$ & Mar 19 & Gallbladder \\
\hline 14 & K.I. & 40 & $\mathrm{~m}$ & $\operatorname{Mar} 20$ & Lung \\
\hline 15 & $\mathrm{M}, \mathrm{G}$ & 78 & $\mathrm{~m}$ & Mar 26 & Rectum \\
\hline 16 & D.G. & 67 & $\mathrm{f}$ & Apr 14 & Goitre \\
\hline 17 & J.F. & 81 & $\mathrm{~m}$ & Apr 15 & Gallbladder \\
\hline 18 & D.E. & 56 & $\mathrm{f}$ & Apr 16 & Rectum \\
\hline 19 & $\mathrm{G} \cdot \mathrm{M}$ & 68 & f & May 3 & Goitre \\
\hline 20 & B.K. & 41 & $\mathrm{~m}$ & May 4 & Lung \\
\hline 21 & R.H. & 34 & $\mathrm{f}$ & May 6 & Gallbladder \\
\hline 22 & $\mathrm{~T} . \mathrm{G}$ & 72 & $\mathrm{~m}$ & May 8 & Goitre \\
\hline 23 & J.F. & 71 & $\mathrm{~m}$ & May 9 & Bypass \\
\hline 24 & M.G. & 77 & $\mathrm{~m}$ & May 18 & Bypass \\
\hline 25 & Sch.K. & 60 & $\mathrm{~m}$ & May 19 & Bypass \\
\hline
\end{tabular}

Age distribution (years, median and range):goitre 68 (38-72), lung 41 (38-74), gallbladder 54 (34-81), rectum 63 (39-78), bypass $73(60-77$ ). Sex distribution (male/female): goitre $1 / 4$, lung $4 / 1$, gallbladder $2 / 3$, rectum $2 / 3$, bypass $5 / 0$

- chemotherapeutic agents (penicillin $G$ sodium, Penicillin "Grünenthal" (Grünenthal), cefuroxim sodium, Zinacef(Hoechst, Glaxo) - erythrocyte concentrates from our local blood bank. They were dissolved in saline immediately before use and passed through a microfilter with pores of $10 \mu$ diameter (Mikrofiltrationsgerät MF 10, Biotest).

Other materials in the study included those for plasma histamine assays which were described in detail in a previous article (Lorenz et al. 1972).

\section{Experimental Design}

The investigation in an individual patient started in the afternoon before the day of operation. From the routine operation programme two surgeon assistants as members of the executive group (W.D. and B,G.) selected the subject by proceeding in the randomization list. Then they checked the availability of the surgeon (H.D.R.), anaesthetist (H.L.) and observer (W.L.) for the first operation at the next morning since every operation in the trial was carried out as the first intervention of the particular day. If this was the case and the patient gave his informed consent to the operation and procedure next morning he was admitted to the trial. Then a questionnaire was completed by one of the two members of the executive group on case history for allergic reactions (Lorenz et al. 1982), a central catheter was inserted into the right atrium and its position was confirmed by $\mathrm{X}$-ray. Thereaftet the first blood sample was taken for plasma histamine and catecholamine assays.

The next morning the surgeon, the anaesthetist and the observer met in the preparation room. The observer was supported by two technicians, and this team conducted the whole clinical "experiment" with fixed and well-defined functions.
(1) The anaesthetist started the "experimental" part of the operation immediately before skin incision. He took all blood samples for plasma histamine assays and determination of acid-base balance values, he measured blood pressure and heart rate supported sometimes by a junior anaesthetist, established clinical signs and biological reactions - if necessary after discussion with the surgeon or/and the observer.

(2) The surgeon with his assistants performed all operations himself from skin incision to skin suture! He took additional blood samples from aorta or portal vein and bile samples before cholecystectomy for amine assays.

(3) The observer meticulously kept watch on all events occurring both in anaesthesia and surgery and dictated them to one of the technicians who was responsible for the protocol of the actual "experiment". He dictated also clinical signs and reactions established by the anaesthetist. He prepared the syringes for plasma samples and asked for blood-sampling at the fixed times during the operation and at special events suggesting amine release or cardiovascular disturbances at these times ("free samples"). Final$l y$, he took care of the samples by cooling them down in an ice-bath.

(4) The first technician filled-up the protocol of the actual investigation (Table 3). She wrote from dictation by the observer, interviewed the anaesthetist about drug applications or other anaesthetic procedures and recorded exactly the time of all events by stop watch. She collected every additional protocols (X-ray etc.) after the operation and recorded every significant event occurring in the patient until his discharge from the hospital.

(5) The second technician took care of all blood samples and prepared plasma immediately after taking according to Lorenz et al. (1972). For this she had to leave the operation theatre on several occasions during the course of a single operation.

The operation was carried out in the patient under routine conditions except for more intense observation than usual and additional blood sampling. The members of the executive group fulfilled their described functions until the skin suture was completed. The patient underwent one of the five standard operations which were selected for this trial (Table 4). Phases of operation were determined at which blood should be taken for plasma histamine and catecholamine assays and measurement of acid-base balance values (for thyroidectomy see Table 3 , for the other operations see Fig. 3 in Results). The five groups of operations were chosen as being more readily standardized than others and rather typical concerning time course and technical performance with well defined decisive phases. Every type of operation was characterized by specific steps in which amine release was suspected to occur, e.g. skin incision, opening of a body cavity, exploration by hand and preparation, removal of a diseased organ, cross clamping of major vessels, removal of vascular occlusion, wound closure.

At the end of operation the exact operation time and the approximately estimated blood loss (volume in the suction apparatus, counting of bloody sponges) were recorded.

In the afternoon of the operation day and in the following days until the discharge of the patient from the hospital again the two surgeon assistants as members of the executive group were responsible for the study. They collected the secretions from drainages for histamine assays and observed the postoperative course. Any serious event such as thromboembolic complications, shock lung ete. was recorded.

\section{Methods, Definitions, Statistics}

Clinical signs being noticed by any of the investigators were discussed and evaluated by the anaesthetist or surgeon and recorded by the observer. They included erythema, wheals, flush, respiratory distress, but also blood losses, cyanosis, muscular movements of the patient and any kind of agitation. In addition the patient's acid-base balance, respiratory parameters, urine production and gastric secretion were monitored.

The timing of any event was performed by a large, standing laboratory stop watch. 
Table 3. Protocol for investigation of cardiovascular disturbances and changes in plasma amine levels in an individual patient during operation. As one example the sheet for a patient with thyroidectomy for euthyroid goitre is illustrated

Group code

Goitre

Introduction of anaesthesia:

\begin{tabular}{|c|c|c|c|c|}
\hline \multirow{2}{*}{$\begin{array}{l}\text { Time } \\
(\min )\end{array}$} & \multicolumn{2}{|l|}{ Anaesthesiological measures } & \multirow{2}{*}{$\begin{array}{l}\text { Surgical measures and } \\
\text { determined phases of operation }\end{array}$} & \multirow{2}{*}{$\begin{array}{l}\text { Blood } \\
\text { samples }\end{array}$} \\
\hline & Drug or technique & Dose & & \\
\hline $\begin{array}{l}\text { Use stop } \\
\text { watch, } \\
\text { record } \\
\text { exactly } \\
\text { the time } \\
\text { of event } \\
\text { [min]! } \\
0=\text { start } \\
\text { of skin } \\
\text { incision }\end{array}$ & $\begin{array}{l}\text { injections } \\
\text { infusions } \\
\text { inhalations } \\
\text { trade names and batches } \\
\text { of drugs } \\
\text { indication for drug } \\
\text { application } \\
\text { stored blood (storage } \\
\text { time, histamine content) } \\
\text { conditions of controlled } \\
\text { respiration } \\
\text { any unusual reaction }\end{array}$ & $\begin{array}{l}\text { mg or ml } \\
\text { infusion or injection } \\
\text { speed (s or min) } \\
\text { relationship of doses } \\
\text { in inhalation (vol \%) } \\
\text { any unusual decision } \\
\text { in drug application }\end{array}$ & $\begin{array}{l}\text { Op-phases with blood sampling } \\
1 \text { before skin incision } \\
2 \text { following ligature of superior } \\
\text { thyroid artery (first manipulation of } \\
\text { the parenchyma) } \\
3 \text { after resection or enucleation } \\
4 \text { before skin suture } \\
\text { Additional samples } \\
\text { retrosternal goitre etc., preparation } \\
\text { of the lower pole etc. } \\
\text { Special events } \\
\text { introduction of plastic material } \\
\text { (drainages, protheses); } \\
\text { injection of contrast media, antibiotics; } \\
\text { complications, deviations from the routine } \\
\text { operation technique; } \\
\text { coordination of any event to heart rate } \\
\text { and blood pressure }\end{array}$ & $\begin{array}{l}\mathrm{ABB}= \\
\text { acid-base } \\
\text { balance } \\
\mathrm{HC}= \\
\text { histamine, } \\
\text { catechol- } \\
\text { amines } \\
\text { Register } \\
\text { additional } \\
\text { sampling } \\
\text { as F1, F2... } \\
\text { etc. }\end{array}$ \\
\hline
\end{tabular}

Table 4. The 5 standard operations selected for trial

Thyroidectomy for euthyroid goitre

Lobectomy or pneumonectomy for lung cancer

Cholecystectomy for gall-stones (elective operation)

Anterior resection for rectal cancer

Aortal-femoral or femoral-popliteal bypass for arterial occlusions in pelvis or lower extremities

The heart rate (ECG lead II) was continuously measured, the blood pressure was recorded either continuously by a Statham pressure transducer or - if not possible for instrumental failure and technical reasons in the turbulent situation at the beginning of an operation - intermittedly, by the sphygmomanometric method.

Plasma histamine levels were determined by the fluorometricfluoroenzymatic method of Lorenz et al. (1972). Two quality control samples were included in every run prepared from pooled plasma of orthopaedic patients in Heidelberg (Lorenz et al. 1982). The specificity of the assay was tested by spectra, heating test including spectra, the reversed blank and in several cases also by incubation with purified histamine methyltransferase. Plasma catecholamine levels will not be reported in this communication.

In this article only single values and medians of these values are shown and submitted to explorative statistical analysis. A pathological plasma histamine level was defined as one exceeding $1 \mathrm{ng} / \mathrm{ml}$ according to Lorenz et al. (1982). Individual increases or decreases in plasma histamine concentrations had to be greater than the 3 S.D. values of the variation of the method (Lorenz and Doenicke 1978). Especially in the picogram range the coefficient of variation was considerably increased for plasma histamine determinations which had to be taken into account: For $300 \mathrm{pg} / \mathrm{ml}$ the 3 S.D. value for imprecision of the assay was $100 \%$ or $300 \mathrm{pg} /$ $\mathrm{ml}$, for $600 \mathrm{pg} / \mathrm{ml}$ it was about $40 \%$ or $240 \mathrm{pg} / \mathrm{ml}$ and for $1 \mathrm{ng} / \mathrm{ml}$ it was about $18 \%$ or $180 \mathrm{pg} / \mathrm{ml}$.
Name:

Weight $(\mathrm{kg})$ :

Start of operation (h):

End of operation (h):
Surgical measures and

Op-phases with blood sampling

1 before skin incision

fllowing ligature of superior

thyroid artery (first manipulation of

parenchyma)

3 after resection or enucleation

before skin sutur

of the lower pole etc.

ial events

(drainages, protheses); operation technique;

and blood pressure

\section{Results}

\section{Feasibility of the Planned Controlled Clinical Trial}

Most of the problems listed in Table 1 could be adequately resolved by the design and the organizational structure of the present study. The executive group consisted of the three heads of Departments, two surgeon assistants (senior registrars) for running the trial the day before operation and the whole postoperative period, and two technicians to support the observer. Additional persons involved were all the subjects routinely working in an operation theatre. The group of external referees consisted of two statisticians, two legal experts, a pharmacologist, two physicians (cardiologist, gastroenterologist) and an external surgeon, especially in the planning phase. Both groups worked well without unacceptable efforts in time and intensity.

The patients could be assigned to the trial at random. The frequency of operations was high enough to allow us to wait for the next case in the list. The small number of operations in April 1981 (Table 2) was caused by Easter holidays and the Congress of the German Surgical Society (1 week). The surgeon and observer completed all operations whereas the anaesthetist had to be replaced by the consultant of the Department in seven patients for reasons of emergency cases in the hospital. This happened by chance 1-2 times in each group of operations.

The surgical techniques could be reasonably standardized (Table 5). There were, however, exceptions which will lead to a modified stratification in future trials: euthyroid goitre may be small or large (e.g. in patient $2560 \mathrm{~g}$ tissue was resected) and more or less retrosternal (very markedly 


\begin{tabular}{lcclll}
\hline $\begin{array}{l}\text { Patient } \\
\text { No }\end{array}$ & \multicolumn{6}{l}{ Operation time [min] } & & \\
\cline { 2 - 6 } & goitre & lung & $\begin{array}{l}\text { gall- } \\
\text { bladder }\end{array}$ & rectum & bypass \\
\hline 1 & 40 & 161 & 53 & 90 & 118 \\
2 & 110 & $73^{\mathrm{a}}$ & 56 & 127 & 171 \\
3 & 89 & 119 & 38 & 112 & 170 \\
4 & 78 & 157 & 65 & 110 & 150 \\
5 & 108 & 155 & 43 & $195^{\mathrm{b}}$ & 155 \\
$\tilde{x}$ & 89 & 119 & 53 & 112 & 155 \\
(range) & $(40-110)$ & $(73-161)$ & $(38-65)$ & $(90-195)$ & $(118-171)$ \\
\hline
\end{tabular}

Table 5. Operation times and intraoperative blood loss in the 5 standard operations

Intraoperative blood loss [m]
\begin{tabular}{lcclcc}
1 & 100 & $2,000(3)$ & 200 & 300 & $1,500(2)$ \\
2 & $2,000(2)^{\circ}$ & $1,200(2)$ & 200 & 500 & $1,300(2)$ \\
3 & 800 & $750(2)$ & 200 & $1,00(2)$ & 400 \\
4 & 250 & $1,200(3)$ & 400 & 300 & 500 \\
5 & 600 & $2,000(4)$ & 200 & $1,300(2)$ & $1,000(3)$ \\
$\tilde{x}$ & 600 & 1,200 & 200 & 500 & 1,000 \\
(range) & $(100-2,000)$ & $(750-2,000)$ & $(200-400)$ & $(300-1,300)$ & $(400-1,500)$ \\
\hline
\end{tabular}

Sequence of patients according to the list of assignment (Table 2)

${ }^{a}$ Palliative operation

${ }^{b}$ Prolonged time due to repetitively suturing the anastomosis by an EEA stapler

"Number of transfusion units given in brackets developed in patient 2 and 5), palliative operations will be established as an additional group. Elevated plasma histamine concentrations were found in such exceptional patients.

\section{Plasma Histamine Levels in Patients Undergoing the Five Standard Operations}

Compared to mean basal plasma histamine levels in several hundred human volunteers and patients (for survey see Schöning et al. 1982) and to those in the four other groups of patients in this study $(0.3 \mathrm{ng} / \mathrm{ml})$ the pre-operative plasma histamine concentrations were twice as high in patients with euthyroid goitre $(0.6 \mathrm{ng} / \mathrm{ml}$, Fig. 2). Whether this finding was obtained by chance or reflected specific alterations in thyroid disease (Feldberg and Loeser, 1954) is an interesting question for further studies. The plasma histamine levels after induction of anaesthesia, but before skin incision (phase 1 in Fig. 2) were normal and did not change drastically during the operation at fixed points of time. A slight increase - exceeding the variation of the method - ocurred only twice during resection of monstrous goitres (patient 2 and 5 in the group, Table 5), but remained always below the critical limit of $1 \mathrm{ng} / \mathrm{ml}$.

The plasma histamine levels determined in the four other groups of patients were compiled in a single illustration (Fig. 3):

(1) During lobectomy or pneumonectomy the histamine values increased only at the end of exploration. On the average the elevation of the plasma histamine concentration was more than 100 per cent (from 0.3 to $0.7 \mathrm{ng} / \mathrm{ml}$ ), in one patient the critical limit of $1 \mathrm{ng} / \mathrm{ml}$ was reached. Another patient showed also a rather high plasma histamine level at the end of resection $(0.9 \mathrm{ng} / \mathrm{ml})$. The values for operative phases 3 and 4 were not determinable in the patient with palliative operation.

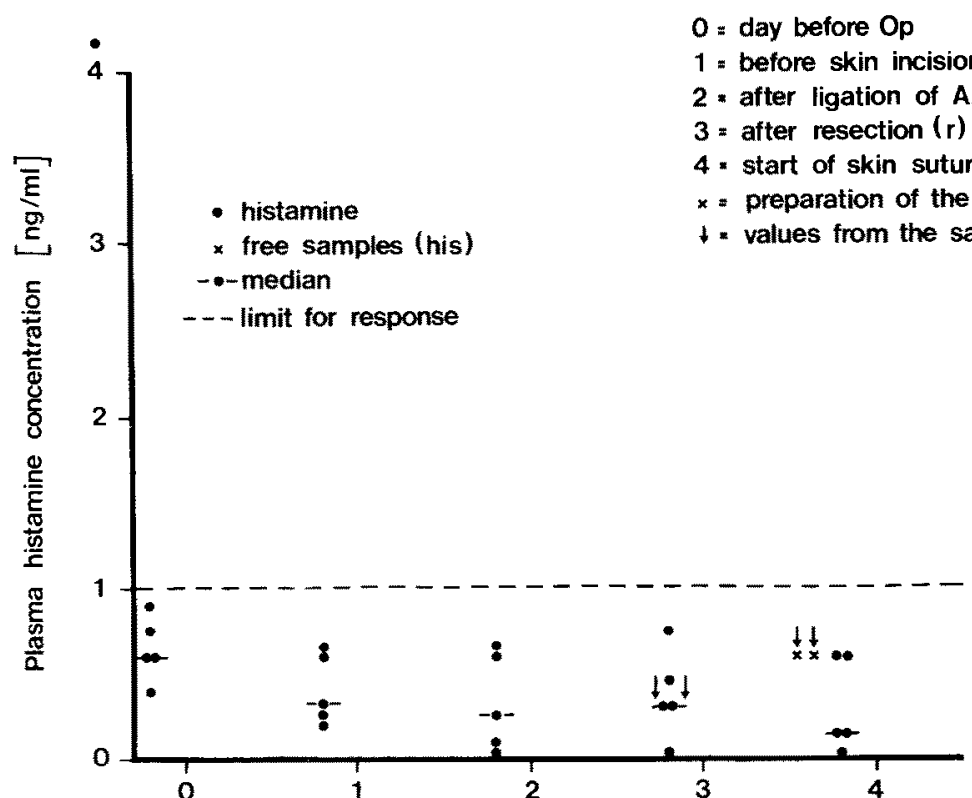

Fig. 2. Plasma histamine levels in patients before and during thyroidectomy ${ }^{1}$

1 Single values obtained from each of the 5 patients, limit for response $=$ cut-off point for a systemic histaminerelease response respectively histamine-mediated anaphylactoid reaction (Lorenz et al. 1982). his= histamine, $r=$ right, $1=$ left. Abscissa $=$ phases of operation [n] 

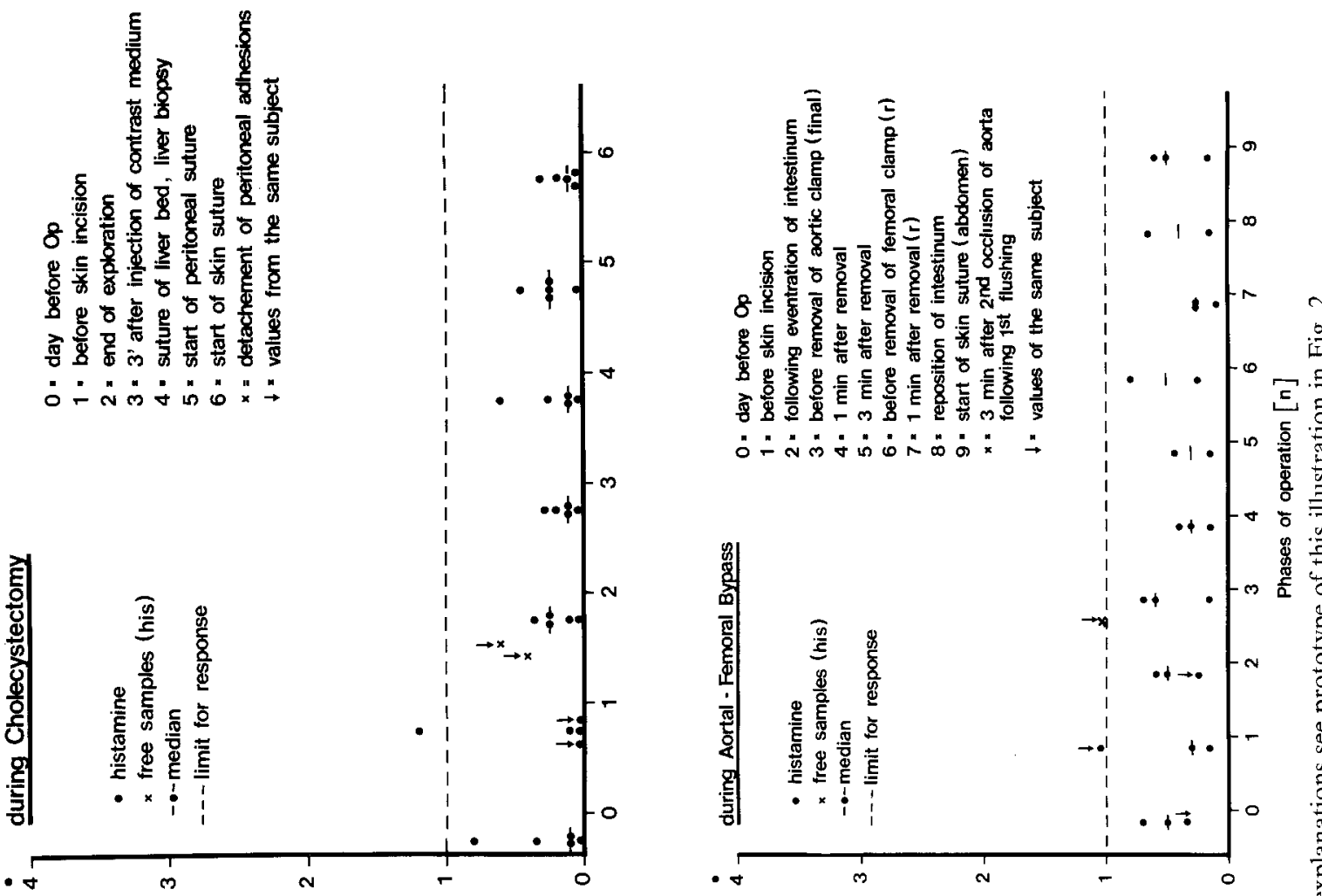

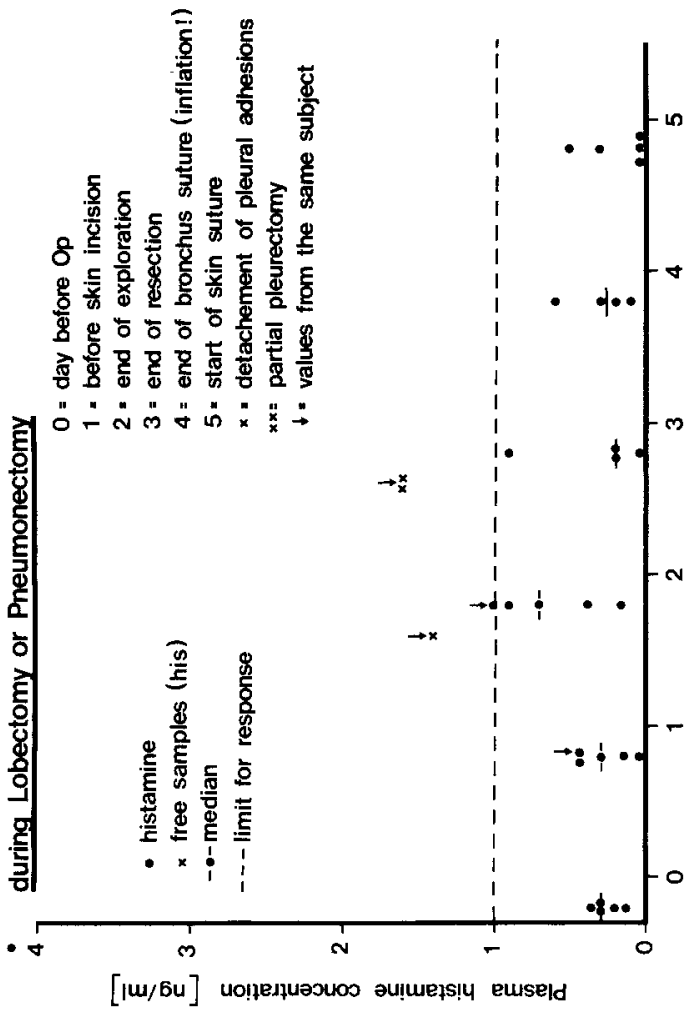

However, plasma histamine levels comparable to an average histamine-release response to drugs (Lorenz et al. 1982) were measured in two free samples: detachement of excessive pleural adhesions due to carcinomatosis and partial pleurectomy, respectively.

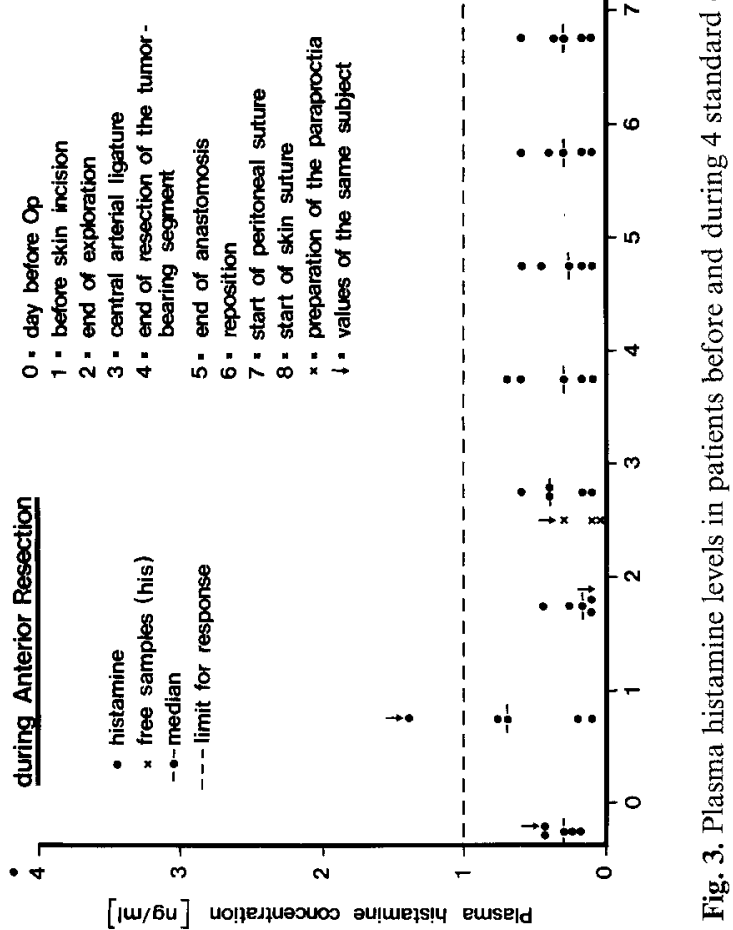

(2) During cholecystectomy a single pathological plasma histamine level was observed after induction of anaesthesia. During operation the histamine concentrations were remarkably low and showed an extremely small variation. Two free samples taken during detachement of peritoneal 


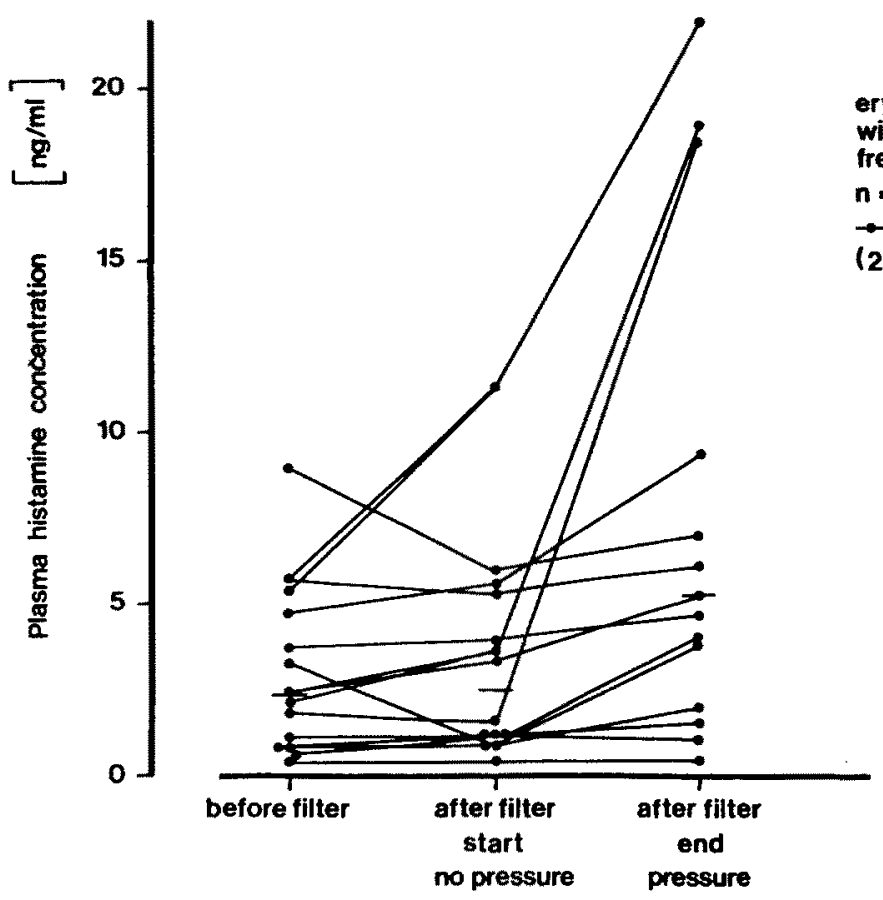

erythrocyle concentrate with $\mathrm{NaCl}$ or fresh frozen plasma $n=14$ $\rightarrow$ median

$(2.4,2.5,5.3 \mathrm{ng} / \mathrm{mi})$ adhesions revealed measurable elevations as well, but none of them attained the limit for a systemic histamine-release response (Lorenz et al. 1982).

(3) During anterior resection of the rectum the second case of undoubtedly elevated plasma histamine concentration occurred after induction of anaesthesia. Since also two other histamine values before skin incision were rather high a mean plasma hitamine level of $0.8 \mathrm{ng} / \mathrm{ml}$ was found after induction of anaesthesia. Thus the subgroup of rectal cancer may be interesting for further studies in anaesthesia.

Otherwise it was rather surprising that the plasma histamine levels did not rise during this type of operation. Even the preparation of the paraproctia with considerable handling of the gut (note the values of free samples in Fig. 3) did not have any influence on them, in remarkable contrast to results obtained in animal (pig) experiments (Lorenz et al. 1973).

(4) In arterial bypass-procedures histamine release was expected to occur especially as a consequence of arterial occlusion (Billings and Maegraith, 1937) and tissue ischemia or hypoxia (Kusche et al. 1981). However, in none of the 3 patients with aorto-femoral bypass nor in the 2 with femoro-popliteal bypass was there any evidence for histamine release. Thus in Fig. 3 the data are shown only for the subjects with aortal-femoral bypass.

In this group of patients the third case of elevated plasma histamine concentration occurred after induction of anaesthesia. This patient, however, received a regional anaesthetic. In addition, in another patient a pathological plasma histamine level was measured in a free sample taken after the first flushing of blood followed by second occlusion of the aorta.

\section{Histamine Concentrations \\ in the "Plasma Stpernatant" of Blood Transfusion}

In 11 of the 25 operations in this study blood transfusions were indicated and conducted as described in Table 5. The
Fig. 4. Histamine concentration in the "plasma supernatant" of erythrocyte concentrates used for blood transfusion. Only 14 of the 27 units administered in the study were investigated. We became aware of this possible source of

"histamine contamination" in the course of the trial total number of transfusion units was 27 . Thus this "drug" application was of great interest concerning histamine contamination or histamine release. However, no fresh blood was administered, but units of erythrocyte concentrates dissolved in $200 \mathrm{ml}$ saline or in 2 cases in fresh frozen plasma were infused after passing a $10 \mu$ microfilter for retention of aggregates etc. (see Materials and Methods). At the start of infusion the suspension ran into the patients under the usual hydrostatic pressure, but very often towards the end of infusion, additional pressure was necessary to achieve a reasonable infusion speed.

Measuring histamine levels in the "plasma supernatant" of such erythrocyte suspensions which were largely cleared from the buffy coat we were surprised to find very high concentrations of free, pharmacologically active histamine (Fig. 4). At the beginning of infusion the median was $2.4 \mathrm{ng} / \mathrm{ml}$. Usually the histamine concentration remained constant after the filter, but under additional pressure by hand pumping they increased markedly in three of the cases (levels in "plasma" corresponding to those of life-threatening reactions (Lorenz et al. 1982)!) and on the average amounted to $5.3 \mathrm{ng} / \mathrm{ml}$. Although such a "histamine" infusion was diluted in the circulating blood volume in two cases in the right atrium plasma histamine values of 1.3 and $1.4 \mathrm{ng} / \mathrm{ml}$ were measured.

\section{Discussion}

Histamine release in surgery by surgical trauma or injury is a problem which has really interested several generations of surgeons and specialists in many medical disciplines (Schneider 1930; Minard 1937; Dragstedt and Mead 1937; Mac Donald and Woolfe 1938; Rose and Browne 1940; Koslowski et al. 1982; Spuzic and Halpern 1959; Rosenthal 1969; Berg et al. 1971; Lorenz et al. 1973; Lorenz et al. 1974; Beger et al. 1975; Markley et al. 1975; Altura and Halevy 1978; Thermann et al. 1978). Findings and hypothe- 
ses sometimes were in favour of a role of histamine in this stressful condition, sometimes against it, but without any exception all authors agree that this role has yet to be defined. This statement is in contrast to the situation in anaesthesia where in the last 10 years the involvement of histamine in adverse reactions to many drugs has been clearly established (Lorenz et al. 1981).

Using one of the two most sensitive and specific methods for measuring plasma histamine concentrations and the sophisticated techniques of a controlled clinical trial in 25 operations it became apparent that histamine release into the systemic circulation is not a general feature of surgical trauma. This information is valuable.

However, histamine comes into the reckoning in distinct phases of surgical intervention, in distinct types of operations and under distinct clinical conditions. In the 25 operations studied in this trial in 8 cases pathological plasma histamine levels $(>1 \mathrm{ng} / \mathrm{ml}$ ) were measured, 3 after introduction of anaesthesia and before skin incision, 2 during exploration by hand, detachement of adhesions and partial pleurectomy, 2 at the end of blood transfusion and 1 after flushing blood and re-occlusion of the aorta in a bypass procedure. None of the elevations of the plasma histamine concentration was so high to cause dramatic, life-threatening adverse reactions in the patients. They corresponded, however, to an average histamine-release response (Lorenz et al. 1982) which in conscious human subjects (volunteers and patients) elicits the clinical signs of a systemic anaphylactoid response (Lorenz et al. 1982). Whether or not such symptoms could be observed in our patients during operative treatment is a matter of meticulous reading and interpretation of our protocols which yet has to be done. In particular the simultaneously determined plasma levels of epinephrine and nor-epinephrine and the effects of the anaesthetics and the other drugs including some with $\mathrm{H}_{1}$ receptor activity have to be considered. Thus at present it is too early to answer the question of whether the elevated plasma histamine levels have any clinical significance.

This trial has never intended to give a definite answer to the question of whether histamine has a function in surgical trauma and which role then the amine is playing in such a complex clinical situation. Its aims were to test the feasibility of a controlled trial of this kind, to develop a model of such a trial, to search for operative phases or events worhwhile to be studied in more specified and then more extended trials, to search for patients with higher risk of histamine release than a general hospital population and to facilitate comparison of the data with those obtained in future with different surgeons and anaesthetists.

At present, this trial cannot be used to recommend strongly a premedication with $\mathrm{H}_{1}$ - and $\mathrm{H}_{2}$-receptor antagonists in surgical patients. There is no evidence that the elevated plasma histamine levels measured with a rather high incidence ( 8 subjects of 25 investigated $=32 \%$ ) are harmful in any direction. It is, however, known that histamine accelerates platelet aggregation and thrombi in normal venules (Begent et al. 1972) and is highly arrhythmogenic (Levi et al. 1980). Thus it is reasonable to suggest that further trials on this question are very worth-while and need to be done. Clearly the possibility exists that the pathological plasma histamine levels demonstrated in this trial are dangerous for the patient in the post-operative period and that a prophylaxis with $\mathrm{H}_{1}$ - and $\mathrm{H}_{2}$-receptor antagonists is worth considering.
Acknowledgement. We thank very much Priv.-Doz. Dr. Fahle for his support of the trial, D. Weber, F. Hinterlang and M. Crombach for their skilful technical assistance. In addition, the critical comments and supervision of the trial by the external referees $(H$. Immich, Heidelberg, Ch. Ohmann, Marburg, H.L. Schreiber and E. Deutsch, Göttingen, D. Owen, Welwyn Garden City, K. Held and B. Clowdus, Göttingen) is very appreciated.

\section{References}

Altura BM, Halevy S (1978) Circulatory shock, histamine and antihistamines: therapeutic aspects. Handbook exper Pharmacol Vol 18/2. Springer, Berlin Heidelberg New York, pp 575-602

Beaven MA, Jacobsen S, Horáková Z (1972) Modification of the enzymatic isotopic assay of histamine and its application to measurement of histamine in tissues, serum and urine. Clin Chem Acta 37:91-103

Begent NA, Born GVR and Scharp DE (1972) The initiation of platelet thrombi in normal venules and its acceleration by histamine. J Physiol (London) 223:229-242

Beger HG, Stopik D, Bittner R, Kraas E, Rescher R (1975) Der Einfluß der Leber auf die Plasmahistaminkonzentrationen. Messungen im prä- und posthepatischen Blut vor und nach abdominellen Operationen. Z Gastorenterol 13:474-478

Berg S, Ditt J, Junze P, Garbe G (1971) Beziehungen zwischen Histamingehalt und Aktivität der Histidindecarboxylase im Bereich von Hautverletzungen. Z Rechtsmedizin 69:26-40

Billings FT, Maegraith BG (1937) Chemical changes in tissues following obstruction of the blood supply. Am J Physiol $27: 249-267$

Blaschko H, Muscholl E (1972) Catecholamines. Handbook exper Pharmacol. Springer, Berlin Heidelberg New York, pp 1-1011

Dragstedt CA, Measd FB (1937) A pharmacologic study of the toxemia theory of surgical shock. JAMA 108:95-96

Erspamer V (1966) Participation of 5-hydroxytryptamine in physiopathological processes. Handbook exper Pharmacol. Springer, Berlin, Heidelberg, New York, pp 360-423

Feldberg W, Loeser AA (1954) Histamine content of human skin in different clinical disorders. J Physiol (London) 126:286-292

Fischer M, Lorenz W, Reimann H-J, Troidl H, Rohde H, Schwarz B, Hamelmann H (1978) Cimetidine prophylaxis of acute gastroduodenal lesions in patients at risk. In: Creutzfeldt $W$ (ed) Cimetidine. Excerpta Medica, Amsterdam pp 280-290

Koslowski L, Marggraf W, Scheele W (1952) Histaminämie nach Muskeltraumen (Crush-Syndrom). Klin. Wochenschrift $30: 365-365$

Kusche J, Lorenz W, Stahlknecht C-D, Richter H, Hesterberg R, Schmal A, Hinterlang E, Weber D, Ohmann Ch (1981) Intestinal diamine oxidase and histamine release in rabbit mesenteric ischemia. Gastroenterology 80:980-987

Laurence DR, Bennett PN (1980) Clinical pharmacology, Churchill Livingstone, Edinburgh, London, pp 1-954

Levi $R$, Allan $G(1980)$ Histamine-mediated cardiac effects. In: Bristow M (ed), Drug-induced heart disease. Elsevier-North Holland Biomedical Press, Amsterdam, pp 377-395

Lewis T, Grant RT (1924) Vascular reactions of the skin to injury (Part II) Heart 11:209-265

Lindenschmidt Th-O, Beger HG, Lorenz W (1981) Kontrollierte klinische Studien: Ja oder Nein? Aufgaben und Grenzen kontrollierter klinischer Studien aus der Sicht des Chirurgen. Chirurg 52:281-288

Lorenz W, Reimann H-J, Barth H, Kusche J, Meyer R, Doenicke A, Hutzel M (1972) A sensitive and specific method for the determination of histamine in human whole blood and plasma. Hoppe-Seyler's Z Physiol Chem 353:911-920

Lorenz W, Hell E, Boeckl O, Reimann H-J, Zimmermann G, Seidel W, Laszez M, Uhlig R (1973a) Histamine release during orthotopic homologous liver transplantation in pigs. Eur Surg Res $5: 11-20$ 
Lorenz W, Seidel W, Doenicke A, Tauber R, Reimann H-J, Uhlig R, Mann G, Dormann P, Schmal A, Häfner G, Hamelmann $\mathrm{H}$ (1974) Elevated plasma histamine concentrations in surgery: causes and clinical significance. Klin Wochenschrift $52: 419$ 425

Lorenz W, Doenicke A (1978) Anaphylactoid reactions and histamine release by intravenous drugs used in surgery and anaesthesia. In: Watkins J, Ward AM (eds) Adverse response to intravenous drugs. Academic Press, London; Grune \& Stratton New York, pp 83-112

Lorenz W, Doenicke A, Schöning B, Neugebauer E (1981) The role of histamine in adverse reactions to intravenous agents. In: Thornton A (ed) Adverse reactions of anaesthetic drugs. Elsevier/North-Holland Biomedical Press, pp 169238

Lorenz W, Doenicke A, Schöning B, Ohmann Ch, Grote B, Neugebauer E (1982) Definition and classification of the histaminerelease response to drugs in anaesthesia and surgery: Studies in the conscious human subject. Klin Wochenschrift, this issue

Mac Donald AD, Woolfe G (1938) Blood histamine in traumatic shock. J Physiol (London) 93:58-59

Markley K, Horáková Z, Smallman ET, Beaven MA (1975) The role of histamine in burn, torniquet and endotoxin shock in mice. Eur J Pharmacol 33:255-265

Minard D (1937) Histamine-like substances in blood following trauma. Am J Physiol 119:375-376
Rocha e Silva M, Rothschild HA (1966) Histamine and antihistamines, Vol 18/1. Springer, Heidelberg, pp 1-991.

Rose B, Browne JSL (1940) Alterations in the blood histamine in shock. Proc Soc Exp Biol Med 44:182-188

Rosenthal SR, Minard D (1939) Experiments on histamine as the chemical mediator for cutaneous pain. I exp Med 70:415 425

Rosenthal SM (1969) Effects of serotonin, adrenaline, noradrenaline and histamine on traumatic swelling. Am $\mathrm{J}$ Physiol $216: 634-637$

Schayer RW (1961) Significance of induced synthesis of histamine in physiology and pathology. Chemotherapia 3:128-136

Schneider H (1930) Über das Vorkommen und über die Bedeutung von Gewebsgiften bei Schockzuständen des Menschen. Arch klin Chir 162:561-563

Schöning B, Lorenz W, Doenicke A (1982) Prophylaxis of anaphylactoid reactions to a polypeptidal plasma substitute by $\mathrm{H}_{1}$ plus $\mathrm{H}_{2}$-receptor antagonists: Synopsis of three randomized controlled trials. Klin Wochenschrift 60:1048-1055

Spuzic TV, Halpern BN (1959) Role de l'histamine dans le choc traumatique. Compt rend scane Soc Biol 253:1108-1110

Thermann M, Largiader F, Lorenz W, Jostarndt L, Neugebauer E (1978) Plasmahistaminspiegel während und nach Nierenallotransplantionen beim Menschen. Langenbecks Arch Chir [Suppl] 1978:303-306

Vane JR, Ferreira SH (1978) Inflammation, Handbook exp Pharmacol. Springer, Berlin Heidelberg New York, pp 1-784 